\title{
Kant on the Relations between Church and State: An Introduction to the Special Edition
}

\author{
- Anna Tomaszewska -
}

\begin{abstract}
This introduction is divided into two parts. First, drawing on Paul Guyer's suggestion that we should turn to Kant to reinvestigate the foundations of religious liberty, I outline Kant's views on the relations between the ethical ('church') and the political ('state') community, as presented in Part Three of the Religion within the Boundaries of Mere Reason, focusing in particular on his arguments for separation between religion and the state. Examining critically the idea to employ Kant in contemporary debates, I claim that Kant's account of pure moral faith and the church as its 'vehicle' may pose difficulties for any argument for religious liberty that appeals to his thought. For Kant is better equipped to offer resources to overcome rather than to accommodate the fact of so-called "moral pluralism," i.e. the condition in which the principle of religious liberty can find its application. In the second part, I summarise the arguments of the authors who contribute to this volume: D. Jakušić, W. Kozyra, S. Lo Re, G.E. Michalson Jr., and S.R. Palmquist.
\end{abstract}

Keywords: Kant, religious liberty, moral pluralism, pure moral faith, ethical community, ecclesiastical faith, church-state relations, secularisation.

Published online: 29 September 2020

1

Full separation between religion and the state may not be the case in even today's largely secularised Western world. ${ }^{1}$ Yet separation between religion and the state is widely recognised as one of the conditions constituting the modus operandi of a secular political regime aimed at protecting such values as freedom of conscience and religious liberty. ${ }^{2}$ Paul Guyer (2018) has claimed, however, that "the principle of religious liberty or toleration" has recently been under attack in the West, ${ }^{3}$ and suggested that we should turn to Kant in order to reinvestigate its philosophical foundations. Kant's argument, on Guyer's reading, does not rely on theological premises, but appeals to the principle of the innate right to freedom that Kant introduces in the Doctrine of Right (cf. MS 6:237-8), which is

\footnotetext{
Anna Tomaszewska

Jagiellonian University

Institute of Philosophy

ul. Grodzka 52

31-044 Kraków

Poland

email: anna.tomaszewska@uj.edu.pl

${ }^{1}$ Cf. Bhargava (2016).

2 Maclure (2017): 25.

${ }^{3}$ Guyer (2018): 310.
} 
supposed to make it superior to the arguments of other advocates of religious liberty and toleration, such as John Locke and Moses Mendelssohn. The topic of this volume critically draws on Guyer's insight that Kant is relevant for contemporary debates on the relations between religion and politics, and also aims to address a more specific question of what exactly a Kantian model of such relations would consist in. The question is important not only to political philosophers seeking inspiration in Kant, but also to scholars of Kant's philosophy of religion that has been gaining increasing attention over the last twenty years. Remarkably, an apparently irreconcilable dichotomy between what one could label 'secular' and 'religious' readings seems to be shaping the dynamic of the debates in this area of Kant scholarship. ${ }^{4}$ The 'secular' interpreters read Kant as a thinker who paves the way to gradually eliminating religion from the political landscape of modern societies; their 'religious' counterparts claim that, for Kant, religion remains indispensable for the realization of the goals of the modern state. Two authors in this volume Gordon E. Michalson Jr. and Stephen R. Palmquist - represent these opposite tendencies. ${ }^{5}$

To outline Kant's model of the relations between religion and politics, it is crucial to engage with Part Three of the Religion within the Boundaries of Mere Reason (1793). Before looking into Kant's arguments more closely, though, it might be useful to explain some of the terminology he employs. Accordingly, religion "subjectively considered" means for Kant "the recognition of all our duties as divine commands" (RGV 6:154; cf. RGV 6:84; SF 7:36; KpV 5:129; MS 6:440, 487). “True religion" consists in "pure moral faith" (RGV 6:112), also referred to as "purely moral religion" and "the religion of reason" (RGV 6:13). There is only one true religion, grounded in reason, but there can be many kinds of faith (RGV 6:108). From pure moral faith Kant distinguishes ecclesiastical faith. The ecclesiastical faith, which serves as a "vehicle" of pure moral faith (SF 7:37; RGV $6: 118,123 n$.), needs revelation in order to be established. Revelation has no moral purport, though, unless interpreted in accordance with the religion of reason (RGV 6:110). By church Kant understands the form in which "an ethical community" (RGV 6:101) is set up that aims to promote pure moral faith. ${ }^{6}$ Kant distinguishes "the church invisible," i.e., "the mere idea of the union of all upright human beings under direct yet moral divine world-governance" from "the church visible," constituting "the actual union of human beings into a whole that accords with this ideal" (RGV 6:101, italics in the original).

Both church and state, as communities (gemeine Wesen), have a public (öffentlich) form and as such are based on laws. Founding a "juridico-civil (political) state" are juridical and coercive laws (Zwangsgesetze). By contrast, an "ethico-civil state" is founded on the laws of virtue, which are non-coercive (RGV 6:95-6). Since compliance with the laws of virtue presupposes freedom, it cannot be enforced by the community, unlike

\footnotetext{
${ }^{4}$ Chris L. Firestone and Nathan Jacobs (2008) have accordingly staged an imaginary trial of Kant's philosophy of religion, featuring (in Part 1 of their book) its prosecutors and defendants.

${ }^{5}$ Palmquist's has been termed a 'religious interpretation' also in: Firestone (2009): 59.

${ }^{6}$ This is not the only way one can articulate the purpose of church, according to Kant; from a different perspective, the ethical community in the form of a church provides Kant's solution to the problem of radical evil in human nature, identified in Part One of the Religion. But introducing Kant's church as a community essentially aimed at propagating moral faith does not remove the point about evil: for it is only as a moral community that the church can play its due role in individuals' conversion and overcoming their propensity to evil.
} 
compliance with juridical laws. Moreover, compliance with juridical laws is possible without adherence to the laws of virtue. Since the political state (or condition (Zustand); see RGV 6:95-6) is founded on coercive laws, it cannot enforce or sanction compliance with the laws of virtue: participation in and following the laws of the ethical community remains therefore outside the jurisdiction of the state. One can think of at least two reasons justifying Kant's contention that conformity with the laws of virtue cannot be enforced. First, since the ground of her moral motivation is epistemically inaccessible not only to others, but also to the agent herself (see, e.g., RGV 6:50), there is no effective method of verifying whether an individual adheres to the laws of virtue, i.e. whether she acts genuinely morally or only legally (cf. KpV 5:151-2; MS 6:214, 219). Second, since following the laws of virtue requires freedom, enforcing these laws would thwart the possibility of an agent following them, and consequently would destroy the very foundation of an ethical community. Kant's distinction between the ethical and the political condition motivates the separation of ethics and religion from politics - or the church from the state - as a corollary of the different 'natures' of the respective public entities (öffentliche gemeine Wesen). Kant expressly states that welding the two communities together would eventually compromise the ends of both:

But woe to the legislator who would want to bring about through coercion a polity directed to ethical ends! For he would thereby not only achieve the very opposite of ethical ends, but also undermine his political ends and render them insecure (RGV 6:96).

Kant himself fell victim to the policy of restricting freedom of inquiry under the guise of protecting the Christian faith. In 1788, Johann Christoph von Wöllner, the minister of conservative Frederick William II, promulgated two edicts - on religion and censorship - intended to curb the 'proselytising' activity of preachers and authors disseminating "radical religious rationalism." ${ }^{7}$ As a result of Wöllner's 'reforms', all writings on religion had to be submitted before publication to an "Immediate Examination Commission" that would assess whether they do not challenge the state's religion. This meant that even those publications on religion that did not fall into the area of theology had to be examined by the clergy. In 1794, on the basis of Wöllner's confessional policy, Kant was accused of "misusing his philosophy to distort and disparage many of the cardinal and basic teachings of the Holy Scriptures and of Christianity" (SF 7:6). In the same year, an essay by Kant was published, titled The End of All Things, in which Kant develops his ideas about Christianity as a "liberal religion," elaborating on his argument for separation between church and state (EAD 8:337-9). If the state imposes the laws of the church on people, Kant argues, the laws will acquire a coercive nature. People will obey these laws out of the fear of punishment rather than out of love and respect, and will thereby lose their internal motivation to obey them. In this way the church will cease to exist as an ethical community.

\footnotetext{
${ }^{7}$ Hunter (2005): 11.
} 
For Kant, to exist as an ethical community, the church has to be independent from the state, or, as Stephen R. Palmquist argues in this volume, it has to be non-political. However, separation does not preclude (a certain mode of) coexistence; rather, the public dimension of the two types of community necessitates it. But how does Kant envisage this coexistence? To what extent (if any) should one community exert its influence on the other? Should they somehow 'collaborate' - and what would such 'collaboration' amount to? James DiCenso's Kant, Religion, and Politics (2011) can help to address these questions. According to DiCenso:

Kant does not disconnect moral community from existing institutions. Just as subcommunities can act as an ethical leaven in the larger public sphere (a model for his reconstruction of the visible church), reciprocally, the capacity to realize moral laws requires appropriate political conditions. The ethical state is a composite regulative principle guiding our efforts to transform the public sphere toward greater autonomy and inclusivity. ${ }^{8}$

DiCenso reads Kant's Religion as a project which shows in what way one should think of the coexistence of the ethical and the political community to be able to claim that the intertwinement of religion and politics benefits autonomous agency. On DiCenso's reading, Kant holds 'church' and 'state' to be deeply interrelated. By way of an illustration: an authoritarian government will not only fail to foster political freedom; it will create conditions that enable perpetuating heteronomous forms of moral agency; ${ }^{9}$ in turn, "authoritarian patterns of belief," 10 which inculcate moral heteronomy, reinforce political despotism. ${ }^{11}$ By contrast, Kant's "religion of reason" aims to promote both moral and political autonomy - "'a true enlightenment' described as 'an order of law originating in moral freedom'."12

However, employing Kant's doctrines in contemporary contexts may run against some difficulties - and I will spend the rest of this section discussing one of them. The difficulty is this: given that Kant recognises one 'rational religion', how can his account of the church-state relations accommodate the fact of what has been called "normative fragmentation"13 or "moral pluralism"? ? ${ }^{14}$ An attempt at a solution can be found, for example, in Onora O'Neill's Kant on Reason and Religion (1997). According to O'Neill, in Kant's view, religion addresses the "reasoned hope" that moral agency can find its adequate expression and fulfilment in the empirical world, ${ }^{15}$ and so that the "gulf" can eventually be bridged between freedom and nature. ${ }^{16} \mathrm{O}^{\prime}$ Neill contends, however, that for Kant "the context of

\footnotetext{
${ }^{8}$ DiCenso (2011): 249.

9 See Kant's consideration of "mercenary faith" (RGV 6:115).

${ }^{10}$ DiCenso (2011): 269.

11 See ibidem: 268-282.

12 Ibidem: 259.

${ }^{13}$ See Palmquist's article in this volume.

14 Maclure (2017): 22.

${ }^{15}$ O'Neill (1997): 269.

16 Ibidem: 304.
} 
action may but need not be framed by the life of a church;"17 other ways in which rational agents can work towards "insert[ing] the moral intention into the world" 18 are equally legitimate. Secular communities, besides the religious ones, can and do promote the ends of practical reason. ${ }^{19}$ For O'Neill's model to work, the Kantian state should be thought of as ensuring peaceful coexistence of different faiths and confessional practices, along with their secular counterparts. But can this model really work with Kant's credentials? There are some concerns which make a positive answer to this question less likely.

Accordingly, Kant locates the source of pure moral faith in reason, whereas revelation is supposed to give rise to "historical faith, merely based on facts" (RGV 6:103). Thus, while the moral faith is rational, hence a priori and necessary, the historical faith is contingent upon experience. Like a Platonic idea in relation to temporal objects, Kant's religion of reason can do without revelation, constitutive of particular ecclesiastical faiths. In turn, the ecclesiastical faith "is mutable and must remain open to gradual purification until it coincides with religious faith" (SF 7:42). Kant depicts the moral progress of humanity as implying the casting off of "the leading-string of holy tradition, with its appendages, its statutes and observances, which ... become bit by bit dispensable" (RGV 6:121). Since the plurality of ecclesiastical faiths derives from historical contingencies, the more we approximate the religion of reason, the less these contingencies will be relevant. The realisation of the ideal of rational faith is thus supposed to lead to overcoming the fact of pluralism. Rather than accommodating "normative fragmentation," Kant envisions eradicating the differences that might be constitutive of what particular ecclesiastical faiths are.

Reiner Wimmer (1990) has noted that there is "a certain inconsistency in Kant's whole conception of the relation of the actually existing churches ... or of the Christian faith based on revelation and ecclesiastical faiths to the pure moral faith of religion." 20 The ecclesiastical faith, as said above, provides a 'vehicle' of the moral faith - a tool for promoting the religion of reason. But if ecclesiastical faith is requisite for promoting the moral faith, why does Kant postulate its gradual decline in the course of moral progress? Arguably, the 'vehicle' as such does not have an intrinsic value and plays a merely subsidiary role, hence can be discarded when it ceases to be requisite. But then, how can moral faith be spread by means of something which has no moral significance, such as arbitrary "statutes" of an ecclesiastical faith? ${ }^{21}$ Bernd Dörflinger (2012) makes it clear that to pass for a 'vehicle' of the moral faith, a historical faith should undergo a kind of modification or reform. ${ }^{22}$ Kant's rules and examples of scriptural exegesis, put forward in The Conflict of the Faculties (SF 7:38-45) and the Religion (RGV 6:110n., 159-161), suggest the direction such a reform could take. However, Dörflinger contends, as a result of the reform, the historical faith shall be attributed symbolic meanings. Such an exegetical

\footnotetext{
17 Ibidem: 306.

${ }^{18}$ Ibidem: 282.

${ }^{19} \mathrm{O}^{\prime}$ Neill's reading fails to explain, however, why Kant gives preference to religion, or more specifically, to the church as an ethical community, as a 'means' of introducing morality to the world. See, e.g., Demiray (2017): 43 n. 48.

20 Wimmer (1990): 204 (trans. A.T.).

${ }^{21}$ See ibidem: 205.

${ }^{22}$ See Dörflinger (2012): 168.
} 
approach must lead to a distanced, (quasi-)aesthetic attitude to historical faiths. "From the viewpoint of the orthodox representatives of historical religions," avers Dörflinger, such an attitude might be interpreted as a hallmark of "the phenomenon of decadence," 23 the demise of religion in a secularised world.

Finally, by Kant's lights, many (if not most) of the existing religious faiths would not qualify as a 'vehicle' of the moral faith. Kant himself excluded Judaism from his ethical community as a merely "statutory faith" (RGV 6:126), established for political purposes, ${ }^{24}$ and Islam as a "fetish-faith" (RGV 6:193-4). Although he perceived Christianity as the best candidate for the 'vehicle', his account of the "true (visible) church" does not seem to match any of the existing confessions (RGV 6:101-2), at least because no existing faith seems to be established in accordance with Kant's four conditions of the true church taken jointly ("universality," "purity," "freedom," and "unchangeableness"). The point is not that religions may not have anything, let alone some moral content, in common, but rather that the moral content need not constitute the core of an existing faith. Nicholas Tampio (2014) has argued for the inclusivity of Kant's 'church', adducing examples of recent developments in Islam towards a more rational conception of faith which acknowledges pluralism and the need for secular state to sustain it. But, with this example, it becomes clear that Kantian inclusivism hinges on the openness of particular faiths to modifications and reforms along the lines of the rational faith. However, the extent to which this project is likely to succeed can be questioned. Allen Wood (2011), for example, does not share Tampio's optimism. Wood says:

Human culture has tended toward a profound split between religious culture and secular culture. Religious thought of all sorts tends to regard itself as a bastion of resistance against 'the Enlightenment' while the rationalist values through which Kant hoped to reform religion are often defended by secularists only in an openly anti-religious form. ${ }^{25}$

If, as Guyer proposes, Kant's arguments are to be read as grounding religious liberty, it seems that the aforementioned concerns cannot be ignored. Of course, the principle that Guyer mentions and the fact of "normative fragmentation" or "moral pluralism" belong, logically, to two different categories - and one could criticise the fact of pluralism while supporting the principle of religious freedom. We can imagine, or perhaps even point to a state which subscribes to the value of religious liberty, and respects what Maclure has designated its modus operandi, without having to deal with the fact of pluralism. Yet, at the level of application, it is difficult to see how the principle could work without the proper context for its exercise, and this context is provided by the fact that people subscribe to different worldviews, values, and creeds (including no creeds at all).

\footnotetext{
${ }^{23}$ Ibidem: 173 (trans. A.T.).

24 "Strictly speaking Judaism is not a religion at all but simply the union of a number of individuals who, since they belonged to a particular stock, established themselves into a community under purely political laws, hence not into a church ..." (RGV 6:125).

${ }^{25}$ Wood (2011): 149.
} 
The above concerns are but a sample of some of the intricacies of Kant's considerations on religion and politics. The five contributions contained in this volume represent diverse interpretive approaches to these considerations and invite further discussion and research in this area.

Dino Jakušić discusses Guyer's (2018) proposal of appealing to Kant in order to reinvestigate the modern foundations of religious freedom. Jakušić contends that Kant's account of these foundations fails to adequately address the problem of what, applying the logical vocabulary of Christian Wolff, he calls dogmatic conflict. Dogmatic conflicts arise when two inconsistent propositions are claimed, by individuals or groups, to have the status of a dogma, by which Wolff understands a universal and demonstrated truth. A dogmatic conflict can arise, for example, between a person who holds a belief based on scientific grounds and a person who holds a belief which is justified by recourse to divine revelation, such as the Biblical story of creation. Jakušić argues that Wolff's metaphysics, which aims to provide a universal method and criteria for finding the truth, can help in the resolution of such conflicts, which tend to occur also today. Wolff's account seems to have an advantage over Kant's in that it does not demand that religious claims be attributed a different meaning than the scientific ones, or, in Kant's terms, that they be interpreted as practical rather than theoretical propositions. Hence, Wolff's account meets the needs of those who would like to consider religious truths on a par with the truths of physics and mathematics. However, Jakušić admits, Wolff's model has its shortcomings, for although it offers a univocal conception of truth and builds a unitary framework within which all claims, religious no less than scientific, can be interpreted and truth-valued, it falls short of preventing conflicts that might result from the misuse of Wolff's method by different groups and individuals claiming to be in possession of the ultimate truth.

The problem of religious toleration emerges in the article by Wojciech Kozyra, which discusses Kant's views on Judaism against the backdrop of some of the biographical details of Kant's relationships with representatives of the Jewish minority. Kozyra sets Kant's views in a comparative context primarily against Baruch Spinoza and Moses Mendelssohn. According to Kozyra, Kant is ambivalent in his assessment of the Jewish contribution to the Enlightenment culture: while he recognizes that as global traders the Jews work towards worldwide peace, his attitude to this nation reflects stereotypes typical of eighteenth-century intellectual circles. Following Spinoza, Kant depicts Judaism as a political organisation, founded on laws regulating external behaviour and valid for a particular community alone. Kant denies thereby to Judaism the status of religion in the proper sense of the word. But, Kozyra observes, unlike Spinoza, who would consider Moses the lawgiver of the Jewish polity, Kant identifies the lawgiver of the Jews with God and thus shows that Judaism operates with an inadequate, particularistic, and exclusivist conception of the divine. Despite initial attempts at collaboration, Kant also remains a philosophical opponent of Mendelssohn. The latter promoted participation of the Jews in the development of the Enlightenment culture, but argued for separation between church and state so as to secure equal rights for the Jews who would adhere to their faith in accordance with their conscience. Kozyra emphasises that whereas Mendelssohn 
advocated a multiconfessional Rechtsstaat which would form a unity (Einheit) out of a plurality of faiths, Kant's preferred model of the state was one based on common moral principles to which different faiths could subscribe as foundational. Kant's favouring Christianity as a vehicle of the moral religion, itself the end of the enlightenment of humanity, raises doubts about his commitment to religious toleration: for if Judaism hinders the moral progress of humanity, and if the Jews are to be citizens of the modern state, they should abandon their original faith and/or convert to Christianity. Despite these contentious moves, Kozyra concludes, a constructive dialogue between Kant and Judaism has been a fact.

Stefano Lo Re outlines the requisite conceptual foundations for an account of the relations between ethical and political community, seeking to compare the state of nature and civil condition in Right and in ethics. Lo Re develops a parallel between an ethical and a juridical state of nature and the respective civil conditions, introduced by Kant in the Third Part of the Religion. Despite apparent differences, many similarities between the ethical and the political community emerge. Thus, Lo Re points out, whereas the juridico-civil condition protects individuals' rights by coercive means (the state has a right to inflict punishment in response to violation of rights), ethics remains beyond the political state's coercion. Also, while the juridical condition is limited to a specific territory, the ethical community has a global reach. Yet, Lo Re suggests, given Kant's doctrine of cosmopolitan right and an international legal order, the juridical condition in fact transcends particular communities. Additionally, both kinds of condition, in their actual shapes, fall short of fully legitimating their existence: no state is ever entirely just and no church constitutes a purely moral community, identical with its invisible ideal. The juridical state provides assurance against potential threats of rights violation; likewise, the ethical state offers protection against its members lapsing into a condition in which, succumbing to the evil propensity in themselves, they would morally corrupt one another. Lo Re claims that individuals incur a public commitment to the good upon entering the ethical state, and the ethical state reveals its moral and political dimensions alike, for example by strengthening adherence to juridical laws or providing organisational frames for pursuing non-juridical duties, such as beneficence.

The article by Gordon E. Michalson Jr. explores the implications of Manfred Kuehn's suggestion that Kant's talk about the divine sovereignty of the ethical community is 'a bit strained'. Michalson argues that Kant's conception of the visible church manifests a certain ambiguity, and offers a number of reasons justifying the claim that Kant's reference to the visible church has secularising rather than religious purport. According to Michalson, the ethical community introduced in Part Three of the Religion parallels the kingdom of ends from the Groundwork of the Metaphysics of Morals, from which references to the divine legislator are missing. Michalson emphasises that the duty to create a moral community originates in reason rather than in God's will, thus establishing a 'church' is a rational demand enshrined in the autonomy of moral-practical reason. It is autonomy, a feature marking the proper exercise of our rational capacities, that requires that we transcend ourselves towards a moral community. Moreover, Kant considers the visible church to be a 'vehicle' of pure moral faith, hence a means to the realization of the goal which consists in bringing about the moral progress of humanity. 
But, somewhat paradoxically, if the church's role is to enable transition to the religion of reason and the religion of reason is grounded in our autonomy, then the church, as Kant envisages it, turns out to be an instrument of secularisation. That religion is grounded in rational autonomy follows from this that, as Michalson explains, the 'divine commands' in Kant's 'definition' of religion ${ }^{26}$ refer to moral duties, and the appeal to God manifests our attitude to the duties, rather than identifying their source. Since Kant thinks of God as a moral being, hence a being subject to the moral law, the relation between God and finite agents in the moral community must be 'horizontal', not 'vertical'. Michalson shares thus some insights with $\mathrm{O}^{\prime}$ Neill in that he also contends that Kant makes room for conceiving of the ethical community in merely secular terms.

Whereas Michalson advocates what we could call a secular interpretation of Kant's religion, ${ }^{27}$ the work of Stephen R. Palmquist provides an example of a reading that defends Kant's theological and religious doctrines as not only a consistent philosophical project, but also as central for Kant's philosophy as a whole. ${ }^{28}$ In his article, Palmquist addresses a challenge raised by Philip Rossi in The Social Authority of Reason. The challenge amounts to two questions: How can Kant's moral ideal be implemented in social practice? And: Can Kant offer a remedy for "normative fragmentation" that contemporary societies have to deal with? Palmquist argues that the challenge can be met once we acknowledge that Kant's ideal of the moral community has primarily a religious and not a political dimension. For Kant, according to Palmquist, moral community can be actualised only in the form of a church. Thus, insofar as the highest political good - perpetual peace - hinges on the moral progress of humanity, it is the church, rather than any political organisation, whose contribution proves vital in reaching this goal. Palmquist spells out four conditions which Kant holds to found the true (visible) church, and insists that such a church must be non-political - this emerges as evident, for example, in the relation of its members to one another and in the relation of its members to God, based on partnership. The true church, developing its moral core, promotes peace, unlike false ones that avail themselves of various coercive means in pursuing merely political ends. Accordingly, Palmquist proposes non-coercive theocracy as a form of the civil condition that comes closest to the ideal of the invisible church. ${ }^{29}$ On Palmquist's interpretation, although religion is requisite to bring about the very goal of political organisation, i.e. lasting worldwide peace, it can do so only by taking a non-political stance. Kant envisages the relations between church and state as based on mutual collaboration, which

\footnotetext{
${ }^{26}$ See the passage quoted in the first part of this introduction (RGV 6:154).

${ }^{27}$ Michalson (1999) identifies a tension running through Kant's philosophy between autonomy and theistic belief, which he considers mutually incompatible (14), and concludes that eventually Kant's thinking drifts towards "a non-theistic direction" (20). On Michalson's reading, Kant's "is not a moral theism struggling to reconcile itself with modernity and a new-found conception of human autonomy, but a radical version of autonomy coping ... with the remnants of an inherited tradition and received vocabulary" (21).

${ }^{28}$ Palmquist (2000) argues that Kant rejects anthropocentrism in favour of a theocentric perspective (12) and Palmquist (2019) contends that Kant places "mystical experience" of a transcendent and personal God "at the very heart of Critical philosophy" (51). Firestone, Jacobs (2008) and Firestone (2009) defend Kant's philosophy of religion as a consistent project, and attempt to link it to the Platonic and the Aristotelian metaphysical traditions.

${ }^{29}$ Cf. Palmquist (2017).
} 
rules out the state's instrumental treatment of the church. Palmquist agrees with Howard Williams that the highest good of ethics and politics can be achieved simultaneously and concludes that, when it comes to the problem of "normative fragmentation," recourse to Kant helps only if we interpret his doctrines in religious, rather than secular terms. ${ }^{30}$

\section{References}

In this volume, Kant's works are cited on the basis of the German Academy Edition in the following way: siglum, volume and page number. All sigla used here conform to the indications of the German Kant Society, specified in the website: http:/ / www.kant-gesellschaft. de/en/ks/Hinweise_Autoren_2018.pdf [Accessed on 18 September 2020]. The lists of references inform about the translations of Kant's works into English that each author refers to.

Bhargava R. (2016), “Is European Secularism Secular Enough?,” [in:] Religion, Secularism, and Constitutional Democracy, J.L. Cohen, C. Laborde (eds.), Columbia University Press, New York: 157-181.

Demiray M.R. (2017), “Public Religion \& Secular State: A Kantian Approach,” Diametros 54: 30-55.

DiCenso J.J. (2011), Kant, Religion, and Politics, Cambridge University Press, Cambridge 2011. Dörflinger B. (2012), "Kant über das Ende der historischen Religionen," [in:] Kant und die Religion - Die Religionen und Kant, R. Hiltscher, S. Klingner (eds.), Georg Olms Vg., Hildesheim, Zürich, New York: 159-175.

Firestone Ch.L. (2009), Kant and Theology at the Boundaries of Reason, Ashgate Publishing Ltd., Farnham.

Firestone Ch.L., Jacobs N. (2008), In Defense of Kant's Religion, Indiana University Press, Bloomington, Indianapolis.

Guyer P. (2018), "Mendelssohn, Kant, and Religious Liberty," Kant-Studien 109 (2): 309-328.

Hunter I. (2005), "Kant's Religion and Prussian Religious Policy," Modern Intellectual History $2(1): 1-27$.

Kant I. (1788/1996), Critique of Practical Reason, trans. M.J. Gregor, [in:] I. Kant, Practical Philosophy, Cambridge University Press, New York: 133-271.

Kant I. (1797/1996), The Metaphysics of Morals, trans. M.J. Gregor, [in:] I. Kant, Practical Philosophy, Cambridge University Press, New York: 353-603.

Kant I. (1793/1996), Religion within the Boundaries of Mere Reason, trans. A.W. Wood, G. di Giovanni, [in:] I. Kant, Religion and Rational Theology, Cambridge University Press, New York: 39-215.

Kant I. (1794/1996), The End of All Things, trans. A.W. Wood, [in:] I. Kant, Religion and Rational Theology, Cambridge University Press, New York: 217-231.

Kant I. (1798/1996), The Conflict of the Faculties, trans. M.J. Gregor, R. Anchor, [in:] I. Kant, Religion and Rational Theology, Cambridge University Press, New York: 233-327.

\footnotetext{
${ }^{30}$ Acknowledgements: The editorial work on this special issue has been funded by the grant of the Ministry of Science and Higher Education in Poland within the National Programme for the Development of Humanities, no. 0177/HPRH4/H3b/83/2016. The research for this article has been subsidised by the grant from the National Science Centre in Poland, no. UMO-2018/31/B/HS1/02050, funding the project Between Secularization and Reform. Religious Rationalism in the Late $17^{\text {th }}$ Century and in the Enlightenment.
} 
Maclure J. (2017), “Towards a Political Theory of Secularism," [in:] The Sources of Secularism. Enlightenment and Beyond, A. Tomaszewska, H. Hämäläinen (eds.), Palgrave Macmillan, New York: 21-33.

Michalson Jr. G.E. (1999), Kant and the Problem of God, Blackwell Publishers Ltd., Oxford.

O'Neill O. (1997), Kant on Reason and Religion, [in:] Tanner Lectures on Human Values 18, G.B. Peterson (ed.), Utah University Press, Utah: 267-308.

Palmquist S.R. (2000), Kant's Critical Religion. Volume Two of Kant's System of Perspectives, Ashgate, Aldershot.

Palmquist S.R. (2017), “Kant's Model for Building the True Church: Transcending 'Might Makes Right' and 'Should Makes Good' through the Idea of a Non-Coercive Theocracy," Diametros 54: 76-94.

Palmquist S.R. (2019), Kant and Mysticism. Critique as the Experience of Baring All in Reason's Light, Lexington Books, Lanham.

Tampio N. (2014), "Pluralism in the Ethical Community," [in:] Kant's Religion within the Boundaries of Mere Reason. A Critical Guide, G.E. Michalson (ed.), Cambridge University Press, Cambridge: 175-192.

Wimmer R. (1990), Kants kritische Religionsphilosophie, Walter de Gruyter, Berlin, New York. Wood A.W. (2011), "Ethical Community, Church and Scripture," [in:] Die Religion innerhalb der Grenzen der bloßen Vernunft, O. Höffe (ed.), Akademie Verlag, Berlin: 131-150. 